\title{
Factors That Affect Youth Political Participation in Ethiopia: Its Impacts on the Democratization Process
}

\author{
Getachew Mijana Sabu \\ Department of Political Science and International Relations, College of Social Science and Humanities, Jigjiga University, Jigjiga, Ethiopia
}

Email address:

getachewmijena@yahoo.com

\section{To cite this article:}

Getachew Mijana Sabu. Factors That Affect Youth Political Participation in Ethiopia: Its Impacts on the Democratization Process. Journal of Political Science and International Relations. Vol. 3, No. 3, 2020, pp. 61-69. doi: 10.11648/j.jpsir.20200303.13

Received: July 28, 2020; Accepted: August 12, 2020; Published: September 3, 2020

\begin{abstract}
In the $21^{\text {st }}$ century, young people have become increasingly more organized, more engaged, and more influential in the political process. However, they are not meaning fully taking part in a formal political system which is vital to shape and transform Ethiopian democracy for a better life of a citizen. This study investigates factors that affect youth political participation in Ethiopia, focusing on its impacts on the democratization process. The comparative analysis research design and Qualitative research approach are employed to review different research papers and documents. The research analysis reveals that, lack of political knowledge and adequate education, youth political interest and apathy, economy, socio-centrism attitude and family's pressure, fear, partisan attachment and the incumbent government performances, age and the existing institutional structures of Democracy are the major factors affecting the youth's political participation in Ethiopia.
\end{abstract}

Keywords: Youth, Political Participation, Democratization, Impact, Ethiopia

\section{Introduction}

Youth are the mile stone for the every emerging democratization process in the world. The recent Arab revolutions towards the need for democracy, equality, justice and human rights are fuelled by young generations. This has resulted in a radical political, social and economic change in the Arab world as well as Africa. Particularly, the youth made political pressure in Ethiopia since 2016 has brought a land mark political, economic and social changes to the country including the replacement of gun by ballot, force by consensus, exclusion by inclusion, and lately revolutionary democracy by "Medemer" or synergy. These all changes are paramount show that, the youth political participation can change any policies, ideologies and law of the state.

Even though democratization is a "process through which a political regime becomes democratic" (Encyclopaedia Britannica) its realization needs participation from the bottom.

The power of the young people in decision making process can benefit their people and youth themselves.

The presence of young people in decision-making positions benefits all citizens and not just youth [29].
According to African Union's report, young people as a critical cornerstone for the realisation of integration and can play a dynamic role in the international arena [1]. Turcotte also argue that, "...public participation in groups or organizations is known to have a positive impact on communities, in particular from a social capital development perspective" [28]. As also stated in [9] "Young people are increasingly recognized as significant agents in community and national development. Throughout the world, hundreds of thousands of young people are spearheading positive social change - leading community initiatives, operating small businesses, and re-shaping political processes." As Singh etal, argue "participation of young people is considered meaningful when they are structurally engaged in all layers of decision-making" process [27].

Whatever roles they play as adults, from leaders of countries to individuals who require help simply to stay alive, this population will one day determine national, political, economic and educational policies throughout the world [11].

Therefore, paying attention youth participation is more important in a societal development as a general. More, to pay attention to youth is to pay close attention to the topology of the social landscape [8]. 
Today, youth political participation is becoming the hot issues throughout the globe and it considered as the alternative way of development. Thus way the world governments are paying attention. For instance, "the AU has over the years adopted normative frameworks to entrench the protection and promotion of young people's rights, including their right to participate in governance, democratic processes and decision making structures at all levels.

To concrete the importance of youth political participation some world organizations and institutions are using the most powerful messages in each of their reports. For example "Youth are the major stakeholders of today and tomorrow" [31]. Besides this, young people are joining together to demand a voice in the decisions that affect their lives [12].

Political participation might increase citizens' knowledge and competence about specific issues, and also, perhaps more importantly, about the nature of political process and even their own rights as citizens [25] as well as "participation does make better citizens"[18]. For instance, those who participate exhibit greater levels of satisfaction with their political system. Moreover, levels of political and civic participation and engagement are also an effective gauge of social and political inclusion, and engaged citizenry are a useful measure of the degree to which democracy is democratized. Sen and Drèze argue that political participation is valuable because of its effects on the individual citizen and its relationship to political system, regardless of the actual outcomes from political processes which has cited in [25].

However, partisan attachment, apathy, lack of political knowledge, influence of the ruling Cadres, low performance of the government, the institutional political system, economic interest, socio-cultural influences as basic negative factors for youth political participation in the democratization process [21]

In the Ethiopian context, it is better to identify the problem that affecting youth political participation besides the all above mentioned factors. Uniquely, Ethiopian youths are actually participating in informal politics like protesting, demonstrations and the like but not in the conventional political system like election, public meeting, and in party membership. Thus way a further study is needed.

\section{Statement of the Problem}

Youth are not just future citizens of the democratic system, but they are active stakeholders in shaping democracy at a given moment [17]. The importance of youth participation has been recognized in several international declarations, e.g. the United Nations Convention on the Rights of the Child (CRC) developed in 1989, the Program of Action (PoA) developed during the International Conference on Population and Development (ICPD) in 1994 [27] and the FDRE constitution of Ethiopia in 1995. In this regard, youth participation can take place in various forms and at various levels. Historically, the Ethiopian youth were known for their informal political participation to overthrow the governments.
For instance, they had made historical movements to end the reign of emperor Hilesilasie I. Next they were involved largely in Dergs development endeavours and marches and later on they were participated in the last civil war that has ended the Derg's regime. Since 1995, the government of Ethiopia has trying to involve youth population into any development activities but lesser in politics and decision making process.

Even though participating in protest, rally and demonstration are regular and common in Ethiopia, many young people are often disenchanted with political structures that are unresponsive to their needs and interests, but they still remain interested in social and political issues and continue to seek recognition from the political system. The country's political system is not only marginalizing youth from political structure but even restricted by rule. Abdullahi argues "marginalization and systematic exclusion of youth from governance and decision making processes through restrictive and prohibitive rules and criteria" used by governments to keep their political interest.

Today in Ethiopia, young people are apprehensive at political participation unlike their elders. Commonly, "African youth are less likely than their elders to engage in a variety of political and civic activities, including voting, attending community meetings, joining others to raise an issue, and contacting leaders [1]. The democratization process in Ethiopia have been aborted many times because of; the government rigidity, interest and political structure (which is not open to participate the entire people, especially young people) and on the other hand, absence of young people formal political participation. Since 2016, thousands of youths were died and many are injured while they are participating in an informal political system bravely to change the regime and its political system. Whatever the method used, the intended goal was achieved bitterly by changing the form and contents of the existing Ethiopian government. Many call this a Transformation: change from an autocratic form of government to a complete democratic form of government. But still the future is uncertain while the young peoples are not yet evolved into the formal political participation to realize their dreams. Many run always to support some political parties without being registered as a member of that party. They usually rally in case of support or oppose any party but they are not yet a member formally. That means, their voice is not yet valued by any party; those in support or by the opposed one. This is a tragedy of youth political participation in the Ethiopian democratization process. However, this study is to investigate what factors are affecting youth political participation and its impacts on democratization process.

\section{Objectives of the Study}

\subsection{General Objectives}

The General objective of the research is to study factors that affect youth political participation in Ethiopia and its 
impacts on the democratization process.

\subsection{Specific Objectives}

1. To identify factors affecting youth political participation,

2. To describe the impact of youth political participation on the democratization process.

\section{Research Questions}

1. What are factors affecting youth political participation?

2. What is the impact of youth political participation on the democratization process?

\section{Review of Related Literature}

\subsection{Lack of Political Knowledge and Enough Education}

Today political knowledge and awareness is a vital body of democratization than ever. Young people are sometimes unaware of what a representative or political career would entail [29]. But they need to know about political institutions and processes, as well as opportunities for participation [23]. They also need to have practical opportunities to engage in civic life and take part in the decisions that are made about the future of their communities [30]. As reason, "youth participation in politics correlates with the opportunities young people are offered" [29]. In such opportunity "youth civic and political education and participation supports stabilization and democracy" [31].

Some recent scholarly literature shows that, "the main factors hindering political participation among the youth are the lack of quality civic and political education" [29]. Thus why, more educated people may be better able to process complex political information [7] quoted in [24] and possess a greater sense of citizen responsibility [24]. The fact that, [e]ducation makes people to be confident in their ability to understand and participate in politics and such confidence may influence the relationships among education, political interest, and participation [2], it can also increase youth political participation. In addition to this, Forgis argues that, “... especially in school life, students seem to have much influence on decision making" and youths would strongly learn what political participation and decision making through group discussion [10].

However, political learning is not only depending on the single aspects of life (school) but more complex from work is necessary. Civil society, politically active families, media, public institutions are actors to activate young people political interests in the democratization process [10]. On the other hand, political socialisation is the indispensable process to develop youth political knowledge. Political socialisation is the process by which a person acquires the necessary skills to function in the political world [10]. And “... it is an ongoing and changing process that occurs over a lifetime (Alwin, Cohen \& Newcomb 1991) Cited in [10]

According to Forbrig, "political socialisation is seen as a way to inculcate politics in young people. Therefore, if young people can learn about and participate in democratic processes and civic life as children and adolescents, then hopefully they will continue this civic participation throughout their lifetime" But this all are nothing without interest and aspiration of youths itself. Indeed, where knowledge gained through experience of democratic processes in everyday life are lacking, political apathy is found with few differences [10].

\subsection{Youth Political Interest and Apathy}

The rate of civic engagement of youth increased over the decade contrary to some non- electoral political activities [28]. The conception of uninterested and passive young people in terms of their relation to politics has become predominant in the social discourse, as far as becoming one of hallmarks of today's youth identities [32]. According to the research analysis, "apparent apathy of young people reflects the frustration with regard to how the political system works, where young people do not find the answers to their needs in a context with less risks and more security.

Debates also became an issue among scholars about young people's political participation, specifically, regarding their low levels of interest in formal politics and the low voter participation. So the result indicates that, the unfavourable situation of young people in the social and political system, their experiences of inequality and social exclusion, as well as the lack of capacity in the field of public decision-making [32]. In addition to this, young people's participation can be explained through the loss of centrality of the political system in social life and the changes in the meanings of political categories.

The major problem is that "... young people distrust unions, governments and politicians because they felt they had no power to influence their decisions or actions" [5]. Even though, they are engaged in political and social issues, they feel alienated by formal, institutionalized politics and are less inclined to engage in traditional forms of participation" [5]. As Raisio, Ollila and Vartiainen argues, youth merely are not interested in the existing methods of political and societal participation [22].

As Norris quoted in Marsh, O'Toole and Jones argues, "political disengagement is thought to affect all citizens but young people are believed to be particularly disillusioned about the major institutions of represent-active democracy, leaving them either apathetic (at best) or alienated (at worst). Apathy has been attributed to young people's increasing individualism and retreat into their private sphere of friends and family, combined with increasing levels of distrust of politicians Kuhar cited in [10].

Marsh, O'Toole and Jones, are clearly explained the idea of Pirie and Worcester's (1998) which suggest “.... the young people... are less involved in politics... less likely to vote in national or local elections and have little knowledge of politics at local or national levels [20].

Henn et al. 2002 and O'Toole et al. 2003 argue that, if we take formal politics, conventional political actors and traditional forms of political behaviour then young people are 
less interested in formal politics than older age groups as cited in [10]. Young people have a different conceptualisation of what constitutes politics, are relatively uninterested in formal traditional political activism, and more participative in localized and immediate issues.

Generally, young people's interest in traditional forms of politics and political parties is said to be declining, which can be seen from the declining levels of voting and membership in youth sections of political parties and youth organizations as a whole Kovacheva's cited in Forbrig [10].

\subsection{Economic Problems}

Young people do not have the resources to engage actively in a context that has monetized politics. Without financial means, 'muscle' it becomes difficult to draw attention [29]. As USAID argues, the existing challenges of youth participation is largely economic. Obviously, lack of opportunity and unemployment is the anti-participation for young people which is spreading to all countries of the world. Unemployment rates among young people everywhere are higher than among adults - averaging to nearly three times the rate of the adult workforce [31]. It also suggest that, “... youth bulge may result in social unrest, war or violent extremism" rather than participating in conventional politics that is considered as the solution for multiple problems.

Bann ell highlights the economic problems of rural youth and its impacts on their political participation as, "large proportions of rural youth are subordinate members of usually large extended households, they are largely dependent on their parents for their livelihood needs" [3]. Therefore, the political participation of this majority would be overridden by chronical economic problems in different country side of the world.

Economic development is the base for institutional arrangements in which it transform the people political attitude as some Asian researches are elaborates;

"... it is the change of institution associated with economic development, rather than economic development per se that transforms people's political behaviour... economic development increases sociological and psychological resources as suggested by the theory but not others.

...the general level of education, income, whitecollar job, political information, and political interests vary with economic wealth" [2].

Indeed, economic problem have major impacts on youth active political participation making them passive, hopelessness and dependent on family.

\subsection{Socio-Centrism and Families Attitude}

Within society, young people develop experiences, shape their opinions and carry out different types of actions around these different groups of political meanings depending on their life circumstances" [32]. Accordingly, their, political participation can be shaped in line with their families activity and group or peer influences. Kotters-Konig, (2002b) and Horowitz, (2007) argues that, the "Emotional relationships and the distribution of power in the family has an impact on the expected political participation of adolescents" (as cited in [10]). They also believe, the experience of regular communication about politics in a family has a direct impact on the political involvement of teenagers.

Traditionally, young people always transfer their political rights to their elder one believing that they can provides everything to their children's and responsible to rule the family. Older people, and especially older males, tend to dominate decision making at all levels in traditional societies [3].

Parsons conceptualises the participation of young people as their integration into the structure of society through internalizing dominant social norms [10]. The social position of youth is accomplished through their involvement in existing institutions and arrangements. Thus participation turns out to be more about controlling young people and regulating their activities in concordance with the requirements of the state system than about their autonomy or self-fulfilment. This understanding has been criticised as biased toward preserving the status quo, perceiving the young only as passive acceptant of adult values and practices (Hartman \& Trnka 1985) as quoted in [10].

Emotional relationships and the distribution of power in the family have an impact on the expected political participation of adolescents as cited in [10]. He also argues that the experience of regular communication about politics in a family has a direct impact on the political involvement of teenagers. The family political back ground and the way they feel politics can influence youth political participation. According to the young people studies magazine, there is a close relationship between the degree of political involvement of the parents and that of their children. The higher the parents' political involvement, the more involved the young people are; the lower, the less politically involved their children are, as well" [10]. He also observed that, the attitudes as well as the political behaviour of young people depending on the parents' ideological orientation and on the different types of political affiliation [10]. He also concludes that [p]olitical culture is not just the result of benchmark political events; it is also influenced by family structure and processes of transmission of values [10].

Youth political interest and participation is not only affected by their family but social attitude. Percy-Smith (1998) identifies negative social attitudes as a key barrier to why young people remain largely excluded from local democratic processes, as cited in [14]. Peoples see youth as a problems in their communities [14]. He also argues that, many adults over 30 associate young people with anti-social behaviour and increased fear of crime. They are seen as the source of troubles or the carriers of problems or deficits [10]. Forbrig seen how society ignores youth in this ways, "young people are seen as lazy, apathetic and egocentric. In the context of democratic participation they are charged with a lack of social and political commitment". In this way, young people felt that they were victimised and not listened to [14]. 


\subsection{Partisan Attachment and the Incumbents Government Performance}

Partisan attachment, or the extent to which voters identify closely with one party over all existing alternatives, represents one factor that influences why younger people may not vote as much as others [24]. According to Converse, more robust partisan attachments among older generations are due to the fact that openness to political learning declines over time [6]. In Africa, through youth leagues and other associations, incumbents traditionally have formed strong attachments with the youth and even encouraged them to engage in political violence [6] as a means for their power preservation.

Regarding's of the incumbent performance, the achievement of ruling party or political elite has great value to sustain one own position or power. How well voters perceive that an incumbent performed in office is a powerful determinant of both the decision to vote and whom to support [15]. Krosnick argues that individuals evaluate incumbents, and policy makers more broadly based on their position and performance on more specific issues that are of greatest importance to them [16]. Indeed, voters may judge a government more on its failure to abide by promises regarding service delivery, job creation, affordable education, and better healthcare [32].

\section{Methodology}

The most appropriate methodology that used for this research is a comparative analysis and qualitative research approach. Since the research is the study of factors that affect youth's political participation in Ethiopia and its impacts in the democratization process, it is appropriate to get in-depth information and data while the area of problem is unclear. The study used a recorded data from different secondary sources of previous researches. The quantitative data is used to support the qualitative one in which a comparative analysis of a reviewed results are mostly qualitative.

\section{Data Analysis and Findings}

\subsection{Lack of Political Knowledge and Adequate Education}

Many young people lack the knowledge of not political participation but the difference between formal and informal political participation. For instance, the majority (77\%) of youths in rural Alge Woreda of Ilu Ababora Zone of Oromia region have clear understandings about what political participation is?" and they really participating in peace full demonstration, protest and community developments actively But they didn't wont participating in the local meeting, election and even not contact with government bodies and parties [21]. This show youth are familiar with the informal political participation which has less impact on their life. But, young people are sometimes unaware of what a representative or political career would entail [29] and they don't know the benefits of taking part in the formal political system than simply protesting or ideally supporting or against for some party.

The young people believe that, they acquired their political knowledge in school and learned from theirs work mates at work places as well as from different Medias [21]. Active families, media and public institutions can make politics more relevant for young people, emphasizing the basic principles of democracy [10]. This does not mean that they have adequate knowledge of the impact of political participation on their life and country as a whole. Because they are not party member, they didn't enroll to election or they are not taking part in local decision making process.

However, today young peoples are remaining passive in formal political participation. This case is true to Ethiopia in which youth are taking civic and ethical education which is aimed to create active and competent citizenship since 1991 GC. As a research shows, "being passive and remaining inactive is not only in political issues but also in their own daily activities are seen as a main problem of youth in Alge Sachi Woreda [21]. Youth remain passive because of lack of practical participation opportunities for young people in schools and beyond school. Contrast to their school education, they express helplessness and resignation over the fact that politics has such a strong impact while they themselves have no possibility to influence the decisionmaking process [32]. Here, they admit that, they can't influence the decision making process while they are not formal in political system. Since, they are politically less skilled and the absence of a socio-political debate which could give their vague sentiments a home, a means to give them a voice, seems a decisive factor for political disinterest [32]. Those politically illiterate youths are dislike formal political participation because of lack of awareness and absence of support and initiation of politicians. But they could do if they provided education for their needs and demands [21]. The Pfaff and Berrefjord's research shows that, young people need to learn through active political participation and through being involved in democratic processes at home, at school, in non-formal education and across third-sector activities in order to become active citizens [10]. Therefore, lack of adequate political knowledge and education is highly affecting youth political participation and their involvement into democratization process.

\subsection{Youth Political Interest and Apathy}

Many research findings show that, the majority of youths have no interest to political participation because of different factors. Specially, they lack interest in the conventional political participation while still they are passively participating in the informal one. Even though they are enthusiastic to political participation, they did not know in which type of political participation they participate. They even assume the informal ones as the right action and engagement to change the public policies. In Ethiopia, for example, 62\% respondents answered the survey question "Do you have an interest to Participate in politics?" 'Yes' while 38\% of respondents answered 'no'. 
Here, the majority of youth have great ambition or interest to participate in politics [21] but they not. In the same manner the research conducted in Spain-Galicia illustrates the fact that youth are not disinterested in politics in a broad sense, and periodically become actively involved in movements, volunteering and social activity [10].

As the responses from interview shows, Alge sachi woreda of Ethiopia, "...most of youths are politically interested but they would not like to discharge their rights and duties...they regret and usually remain inactive...they did not play their role..." [21]. This show, they have interest but not practical and they losing their voice even during the national parliamentary elections.

Whatever their interest of political participation, youth are unable to participate in the formal political participation in the world, and in Ethiopia particularly. They lack practice because of: "lack of respect ion for youths by executive bodies while most of them are self-oriented...no democracy and good governance....absence of infrastructures in the local area... and fear of political punishment." [21]. Politicians do not seem to know or care to know the real needs of the citizens. Issues arise and decisions are taken within a power structure that excludes the man in the street [32].

Other factors are also political mal-practice, corruption and threatening by local leaders to get them involved into their own ruling line undemocratically. According to the Young People Studies Magazine analysis, "apparent apathy of young people reflects the frustration with regard to how the political system works, where young people do not find the answers to their needs in a context with less risks and more security".

Again, youths are in confused to participate or not because of if they refuse, they will be suspected as political rivals while it is their democratic right. On the other hand, when they take parts in different public meetings and conferences and raise some development oriented questions, they will also be ignored and considered as the ones who have negative political attitude for the ruling party.

Generally, in addition to the above immediate factors, youth's uninterested and apathetic in political participation because lack of support and motivation from concerned bodies, corruption around administration, absence of visible development in their local, the non-democratic characteristics of local leaders and the violation of both democratic and human rights by government officials and securities [21]. The normal politics is good respecting the individual freedoms and rights, abstaining from state violence, repression and arbitrariness, and offering the possibility to influence decision making [10].

\subsection{Economic Factor}

The majority (93\%) of youths and their families' livelihood are depending on agriculture [21]. Bennelli argues, youth "lack economic independence" as their common attributes [3]. In addition to these, youth are exposed to economic problem because of unemployment [21]. Therefore, their daily activities go beyond searching of income and they give priorities to improve their life style first. At the same time, they desire to apply their democratic right through participation but they couldn't because of their economic hand short to get access. They are also unable to appear in public meetings, conferences and even voting, because of the economic pressure on their life.

\subsection{Socio-centrism Attitude and Families Pressure}

Usually, the young people political interest affected by society, group, peer or family at large. Sociologically all interests and activities of all children or youths are influenced by their family which is one of responsible social institution in a society. They also dominate the interest of youths to do or not to do whatever they want. Youth have limited social and political power while the elder people tend to dominate decision making at all levels in traditional societies [3].

Family could affect youth's active political participation for different reasons: On one hand, reminding the past history and story they told to them about the negative side of political participation. For example, in Ethiopia, they tell about red terror (the events that happened during Derg regime (1974-1991) and the pain of all political prisoners of post 1991 as the shocking event in the history of Ethiopian politics. This gradually degraded the interest of rural youths in political participation and then it able to makes them passive. On the other way, the majority (58\%) youth families are illiterate and do not participating in politics actively that results the political passivity or apathy of their children's [21] Chaffee argues, the older generation, having grown up under very different socio-political conditions, is often not knowledgeable about democratic processes and institutions, and may not have a strong commitment to democratic values [4].

Most of youths are affected by socio-centrism thinking that they have follow as a guide line in their society. For instance, they believe that war as the only of freedom and democracy. Because of; they assume that, their nations or tribes are suppressed by other nations or tribe. Their languages are dominated by other language's intentionally by government policies. The election is unfair and conducted only to fulfil the interest of the ruling one.

Even though, these social events are true and unconditional in Ethiopia, youths are think what their families think and thought rather than being rational and independent in the search of their democratic rights. They hate the conventional political involvements because they see it as nothing to change the country's socio-political structures as the existing regime is not ready to change. By doing this they are distancing from the participation in which they could bring changes for their life.

In addition to the above factors, the social negative attitude for young people activities in a society including their political participation is affecting youth political participation. Most dangerously, the way, in which local people interpret, understand and perceive the daily activities of youths are negative. According to Mijana, “...the major problems of rural youth is the problem of attitude which is originates from their family as well as society" [21]. The young people grow 
up with the negative attitude to political participation that they have learned from their society. So, they do not take part in the conventional political participation to balance their acceptances in a society unless they will be ignored and named as anti-society as well as source of problem.

On the other way, youth hate political participation because of the negative attitude that they have developed towards the local governments and their response to any social claim. For instance, they claims that, "...there is a problem of implementation of democratic principles around the government offices and individual officers...the ruling bodies or cabinets have attitudinal problems and they treat people classifying by clan and status...individual interests and corruptions have eroded the government offices...no reality in their ruling system...injustice and un equal benefits of people because of misuse of authority by the lower level executives" [21]. This assumption and the realty of this action in governmental offices are making youth discomfort, apathy and wish less for their future life. And this is already accepted by society as none changeable phenomena (morally corrupted society).

\section{5. “Fear" of Consequences After Participation}

Political fear is largely affecting youth's active political participation in Ethiopia. The majority $(41.5 \%)$ youths in Algesachi Woreda's did not participate in politics actively because of fear of politics [21]. That means they fear its consequences after participation whether it is negative or positive. If the youths give support to the political parties that they want or if they are not registered as a member of the leading party, they will be punished or condemned as opposite by local political elites. Therefore, the majority of youths are preferred to be passive on any type of political activity [21].

\subsection{Partisan Attachment and Low Performances of the Incumbent Government}

As different research findings show, youth are very passive and fear political participation because of partisan attachment and its consequences to their life in Ethiopia. For instance, " $55 \%$ of youths are afraid to participate in politics, because of partisan attachment" [21]. This means, if they actively take parts in whatever political issues they want, the ruling bodies specially the kebeles and Woreda's administrators attach them to the opposite parties and then target them to revenge.

On the other ways, absence of visible development in their locals and country's as general made a majority of youths more passive in politics. This show that, any development which has not been under taken by the elected and the currently ruling party or government is gradually decreased the interest of youths towards political participation. Therefore the incumbent government performance in locals and country has completely affected the interest of youths in political participation. For instance, $68 \%$ of youths are remaining passive because of the insufficient performance of incumbent government in their local [21].

\subsection{The Existing Institutional Structures of Democracy}

The existing democracy and its institution are not open and inclusive in Ethiopia. The way the government apply rules and regulations in the country is unconstitutional. The people are also dormant in the democratization process of the country. This are manifested in the way the government bodies' initiation about youth's political participation. For instance, "the majorities (55\%) of are responded 'no' for the question "Do the government officers encourage your political participation?" and $45 \%$ answered 'yes' [21]. This indicates that, the existing democratic institutions are not responsible to youth participation and this problem is majorly affecting the young people interest in politics.

In Ethiopia, the government officers are not encouraging or initiating youth's participation in politics. They didn't initiate them democratically to express their view and opinion to influence the policy makers. No policy made with the consideration and participation of youth in Ethiopia.

On the other hand, youth themselves lacks the awareness and understanding of democracy. For instance, in Ethiopia, $60 \%$ of them have no understanding of democracy [21] while political participation is the base and significant for democratic development. However, to understand and look in the existence of democracy, active political participation may play a great role. Without participation in all social and political spheres, it is difficult to understand what democratization is. As research shows, Democracy is not a spectator sport. A democracy without active citizens is not a democracy [19]. So, the incompatibility of government, political institutions, and youth in Ethiopia indicates, the existing democratic structures are not attractive and challenging youth political participation.

\section{Conclusion}

Many young people lack the knowledge of not political participation, but the difference between formal and informal political participation throughout the globe. The majority of youths in Ethiopia have no clear understandings about what political participation is and actively participating in the informal politics but not in the formal one. Therefore, lack of adequate political knowledge and education is highly affecting youth political participation and their involvement into democratization process.

Young people lack interest in the conventional political participation while still they are actively participating in the informal one. Politicians do not seem to know or care to know the real needs of the citizens.

In addition, youth's un interested and apathetic in political participation because lack of support and motivation from concerned bodies, corruption around administration, absence of visible development in their local, the non-democratic characteristics of local leaders and the violation of both democratic and human rights by government officials and security bodies. 
The Economic problem is one among the factors affecting youth political participation. As a result, they are unable to appear in public meetings, conferences and even voting, in Ethiopia.

The young people political interest is also affected by societal attitude, group, peer or family at large in Ethiopia. So, most of youths are affected by socio-centrism thinking that they have follow as a guide line in their society. In depth, the major problem of youth political participation is the problem of attitude which is originates from their family as well as society.

Political fear (the consequence of participation) is largely affecting youth's active political participation in Ethiopia.

The majority of youth are affected by the existing tradition in their society to participate in politics. This problem arises basically from those elder generations of the country in which they are only focusing on their regular jobs rather than political participation.

In the same vain, many youth groups do not focus on politics in their life because of their restricted religious principles and sometimes by their own attention to their religious activities.

Age is another factor which is largely affecting youth political participation than tradition and religion in Ethiopia. This is arising from the citizenship law and other legal limitations on the youth membership and activities in the country.

Youth are very passive and fear political participation because of partisan attachment and its consequences to their life in Ethiopia. Besides this, the incumbent government performance in locals and a country has completely affected the interest of youths in political participation.

Again, the existing democracy and its institution are not open and inclusive in Ethiopia. The government, institutions and constitutions are not responsible to the youth interest and participation. In the other way, the youth are also passive and apathy in democratization. No compatibilities among the democratic institutions, governments and youth at all in Ethiopia.

\section{References}

[1] Abdullahi. A. (Press Statement, Thursday, 26 January 2017) Commissioner for Political Affairs. Youth Participation and Representation in Governance and Democratic Processes in Africa. AU Headquarters Addis Ababa Ethiopia.

[2] Asian Barometer, (2004). Economic Development and Political Participation: Comparison of Mainland China, Taiwan, and Hong Kong. Working Paper Series. 19p. Asian Barometer Project Office, 2004 Taipei.

[3] Bennell P (2007). Promoting Livelihood Opportunities For Rural Youth. International Fund for Agricultural Development Governing Council Roundtable: Generating Remunerative Livelihood Opportunities for Rural Youth. UK: Knowledge and Skills for Development P 13.

[4] Chaffee, H. (1997), The newspaperasan agentof political socialisation in schools: effectsof "El Diario en la Escuela" in Argentina, paper presented at the annual convention of the
Association for Education in Journalism, Chicago, IL.

[5] Collin P (2008). Young People Imagining a New Democracy: Literature Review P 18.

[6] Converse, P. (1969). 'Of Time and Partisan Stability'. Comparative Political Studies, 2 (2).

[7] Dalton R (2008). Citizenship Norms and the Expansion of Political Participation. Political studies 56 (1): 76-98.

[8] Durham D (2000). Youth and the Social Imagination in Africa: introduction to parts 1 and 2. Anthropological Quarterly, 73 (3): 113-120.

[9] EQUIP3, 2009). Youth Councils: An Effective Way to Promote Youth Participation. Policy Study and Issue Paper Series. USAID. 10p.

[10] Forbrig J (2005). Revisiting youth political participation: Challenges for research and democratic practice in Europe. Council of Europe.

[11] Gigson-Cline J (2000). Youth and Coping in Twelve Nations: Survey of 18-20 year old Young People. Routledge Research International Series in Social Psycholog, California, USA. 297 P.

[12] Ginwright S, James T (2002). From assets to agents of change: Social justice, organizing, and youth development. New Directions for Youth Development 76: 27-46.

[13] Hart R (2009). Charting change in the participatory settings of childhood. In; Thomas. (Ed), Children, politics and Communication: Participation at the margins. The Policy Press, Great Britain.

[14] Johnson V (2009). Children's autonomous organisation: reflections from the ground. In; Thomas. N, (Ed), Children, politics and Communication: Participation at the margins. The Policy Press, Great Britain, UK.

[15] Kagwanja, P. M. (2005). "“Power to Uhuru”: Youth Identity and Generational Politics in Kenya's 2002 Elections'. African Affairs, 105 (418).

[16] Krosnick, J. (1990). 'Government Policy and Citizen Passion: A Study of Issue Publics in Contemporary America'. Political Behavior, 12 (1): 59-92.

[17] Mayer M, Galappatti A (nd). Democracys Future? Youth attitudes towards Governance in SriLanka.

[18] Mansbridge J (1995). Does Participation Make Better Citizens? PEGS Conference, February 11-12, 1995.

[19] Markowitz D (2009). The Impact of Civics Education on the Attitudes, Behaviors and Disposition of Youth. p 18.

[20] Marsh D, O Toole T, Jones S (2007). Young People and Politics in the UK: Apathy or Alienation? Springer 246 p.

[21] Mijana. G. (2013). Factors that affect Rural youth active political participation in Alge Sachi Woreda of Ilu Aba Bora Zone of Oromia Region, Ethiopia. (M. A. Thesis). School of Governance and Development Studies, Hawasa University, Hawassa.

[22] Raisio H, Ollila S, Vartiainen P (2011). Do youth juries enhance youth political and societal participation? Lessons from the Vaasa experiment. SJPA (Scandinavian Journal of Public Administration) 15 (3): 42. 
[23] Rashid M and Gao Q (2012). Determinants of Rural Youth's Attitude and Involvement in Bangladesh Politics.

[24] Resnick D, Casale, D (2011). The political participation of Africa's youth: Turnout, partisanship, and protest, WIDER Working Paper, No. 2011/56.

[25] Shapiro R, Winters M (2008). Political Participation and Quality of Life. Columbia University, Inter-American Development Bank 638: 52.

[26] Sinclair, (2004). Participation in Practice: Making it Meaningful, Effective and Sustainable.

[27] Singh, A. Shewangizaw Tafesse, H., Ali, A. M., Legese Bekele, K., Gamachu, M. \& Reeuwijk, M. van, (2016). "Operations Research on Meaningful Youth Participation in Ethiopia", Rutgers.
[28] Turcotte. M, (2015). Political participation and civic engagement of youth. Canada, Minister of Industry.

[29] UNDP4YOUTH, (2017). Consolidated reply of the eDiscussion on Youth Political Participation.

[30] UNDP, (2013). Enhancing Youth Political Participation Throughout the Electoral Cycle: A Good Practice Guide. UNDP. New York.

[31] USAID POLICY (2012). Youth in Development Policy: Realizing the Demographic Opportunity. Washington DC: U.S. Agency for International Development $26 \mathrm{p}$.

[32] Young people Studies Magazine, 2008). Young People and Political Participation: European Research. Young people's Studies Magazine 2 (81): 222. 